\title{
Predicting Students' Intent to Pursue Retailing as a Career: A Means-End Perspective
}

\author{
Safiek Mokhlis \\ School of Maritime Business and Management, Universiti Malaysia Terengganu, \\ 21030 Kuala Terengganu, Malaysia \\ Email: safiek@umt.edu.my
}

\section{Doi:10.5901/mjss.2014.v5n27p404}

\begin{abstract}
Career opportunities in retailing are rapidly expanding, and there is an increased demand for college graduates into the industry. However, retailing was not regarded by the students to be an attractive career option. The current study identified personal values as underlying motivations, which have received less attention but carry important meanings in explaining college students' choice behavior regarding retailing careers. From the perspective of means-end chain theory, a hierarchical model consisting of personal values, job attributes, and choice behavior has been proposed. Participated in this study were 172 final year business students from two public universities in Malaysia. Multiple regression analysis was used to test the hypothesized relationships. The results show that the values-attributes-behavior hierarchy model can serve as a reliable tool in predicting college students' expected choice behavior regarding retailing as a career.
\end{abstract}

Keywords: Generation Y students, personal values, career attributes, retailing.

\section{Introduction}

For the sake of gaining competitive advantage, the retailing industry has an urgent need to attract and recruit large numbers of qualified people who are capable of creating sustainable profits for their organizations. Business undergraduate students are among these people of high caliber that the retailing industry should be attracting. However, although they are naturally regarded as potential retail managers when they enroll in the business program, these young intellectuals unfortunately show an unwillingness to work in the retailing industry after graduation (Swinyard, Langrehr, \& Smith, 1991; Broadbridge, 2003a; Rahim, 2013; Mokhlis, 2014a). Research suggests that students do not really understand what a job in retailing entails (Commins \& Preston, 1997; Broadbridge, 2003a). Students appear to associate a career in retailing as a predominantly store-based and this is attributed with negative descriptors such as "dull", "poor salary", "routine" (Swinyard, 1981; Swinyard et al. 1991), "hard work" and "long, unsociable hours" (Broadbridge, 2003a, 2003b). Past studies also indicate that students' perceptions of retail careers appear to be influenced by a company's image and types of retail sector, with some sectors more highly rated by students as preferred career destinations than others (Goldsberry, Gehrt, Sun, \& Shim, 1999; Broadbridge, 2003a).

Furthermore, retailers face great challenges in gaining commitment of younger and entry-level employees. Studies have shown that graduates have difficulties in assimilating to work in the retail industry. Retail employees with higher levels of education were more likely to be dissatisfied in their job (Bent \& Freathy, 1997; Whysall, Foster, \& Harris, 2009). Rolfe (2001) noted that today's students are materially oriented towards using a degree to get a job, and are interested in vocational degrees and a lucrative career more so than previous generations. The majority of college students are now part of Generation Y (that is, those born between 1980 and 1994) and they will soon be the most dominant group in the workforce. As employees, it is widely noted that Generation Y's work-related characteristics and attitudes are radically different to those of previous generations entering the workforce (McGuire, Todnem By, \& Hutchings, 2007) and are incongruent with conventional thinking on how new entrants to the labor force should think and act (Glass, 2007; Morton, 2002; Martin, 2005). Particularly distinct of Generation Y over previous generations (such as Generation X and Baby Boomers) is their high expectations for working conditions, pay, promotion, and career advancement (Oliver, 2006). Studies have found that Generation $Y$ want a balance of personal and work goals, social connections and social environment at work, as well as good training and development in an organization (Broadbridge, Maxwell, \& Ogden, 2007; De Hauw \& De Vos, 2010).

Marketing educators have recommended developing a better understanding of Generation $Y$ students' attitude toward retailing for improving pedagogical approaches in university business programs to make careers in retailing more attractive (Broadbridge, 2003a; Broadbridge et al. 2007, 2009). Identifying student perceptions and the factors influencing 
their career decisions may point out areas of retailing careers that require further discussion and elaboration in class. It may be necessary for marketing educators to confront students with arguments and assertions about retailing careers so as to raise levels of consciousness regarding its role in society. Clearly, because business students represent an attractive source of future managers in retailing, this issue is of utmost important to retail corporations.

Considerable research has been conducted to help understand students' perceptions of retailing as a graduate career (e.g. Swinyard, 1981; Swinyard et al. 1991; Broadbridge, 2003a, 2003b; Broadbridge et al. 2009; Mokhlis, 2014a, 2014b, 2014c). However, very few studies have addressed the factors that influence students' perceptions of retailing careers (Shim, Warrington, \& Goldsberry, 1999). The current study approaches from the perspective of means-end chain theory, and intends: (1) to introduce personal values as underlying beliefs to explain students' perceived importance of job attributes, and (2) in turn which job attributes are relevant in explaining students' retail career intention. Examining these relationships provide a useful way to understand the fundamental reasons behind college students' attraction to retailing as a career.

\section{Research Model and Hypothesis}

Personal values are core beliefs which guide various actions and judgments across specific situations. From a cognitive perspective, personal values are the mental representations of underlying needs after taking into account the realities of the world and reflecting the individual's personality (Rokeach, 1973). Rokeach (1973) asserts that values are related to the way one behaves in society or to final states of existence that, once internalized become a criteria that guide attitudes and actions toward relevant situations. The means-end chain theory assumes that personal values could be end goals that a person pursues in his life. These end goals are principles and guidelines and directing a person's evaluations of which attributes (means) are more relevant to achieve these end goals. The means-end chain theory suggests that beliefs, a link, or a relationship between two cognitions, form belief systems in human memory, and that such systems are hierarchical (Grunert \& Grunert, 1995).

A theoretical model presented in Figure 1 is proposed based on a framework of means-end chain theory, into which piecemeal studies on the relationships between personal values, career attributes, and behavioral measures have been integrated (Hojat et al. 1998; Shim et al. 1999; Añaña \& Nique, 2010). The research model postulates a hierarchical cognitive structural model consisting of personal values, career attribute evaluations, and career choice. Personal values are hypothesized to be the end that an individual pursues in life and the underlying beliefs of individuals, which can explain their importance judgments of certain job attributes. Personal values are suggested to be the guiding principles of an individual to evaluate various attributes of a career. The evaluations of various job attributes are hypothesized to represent individuals' means to achieve their desired end-states and eventually become the basis for selecting a specific career. These proposed hierarchical relationships are known as top-down route of information processing (Fotopoulos, Krystallis, \& Mess, 2003; Brunso, Scholderer, \& Grunert, 2004) and were proved to be useful in explaining individual differences in underlying motivations of certain behaviors (Grunert \& Grunert, 1995).

The power of values to influence the assessments made by a person and his/her choices as well as those of others around suggests that human values can drive attitude and behavior, and therefore can interfere in the decisionmaking process related to career choice (Foskett \& Hemsley-Brown, 1999). A few general studies of values in relation to various aspects of occupation may provide some insight into specific manner by which personal values influence career expectation and choice. Hojat et al. (1998) investigated the effects of physicians' personal values on their career choices. The study empirically showed that physicians' personal values are relevant to their career decisions such as specialty choices and expectations of income. A study of Williams and Hall (2006) showed that the organizational values, priorities and attitudes of marketing students and top level marketing managers were significantly correlated to their personal values. In a study on personal values in relation to graduate career choices, Añaña and Nique (2010) found that students choosing some careers are more typical, based on their values, than others, and that some values are more typical of some careers than others. A study of Shim et al. (1999) investigated the relationships between personal values and career choice behavior regarding retailing. This study empirically proved the sequential effects of personal values on retail career attitudes and then retail career choice. 


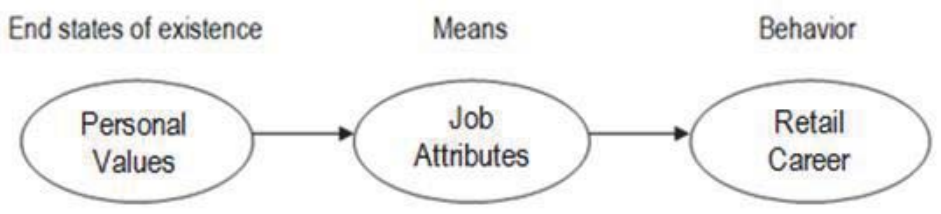

Figure 1: Theoretical model

The following hypotheses were developed based on the literature review and proposed model:

H1: Personal values are directly related to students' perceived importance of job attributes.

$\mathrm{H} 2$ : The importance of job attributes are directly related to the likelihood of students choosing retailing as a career.

H3: Personal values are indirectly related to the likelihood of students choosing retailing as a career.

\section{Methodology}

A self-administered questionnaire was developed to measure personal values, career attributes, and their relationships to retail career intention. Most items indicating personal values, career attributes, and career choice behavior were drawn from the previous literature, which renders more convincing content validity of the measures. Personal values were adopted from the List of Values (LOV) scale, which consists of nine items, namely, a sense of belonging, excitement, fun and enjoyment of life, warm relationships with others, self-fulfillment, being well-respected, sense of accomplishment, security, and self-respect (Kahle, 1983). The items were measured with reference to a seven-point scale $(1=$ not important at all, 7 = extremely important). The LOV scale is particularly suitable for an analysis of this nature and has been commonly used in research on values due to its simplicity of administration and high reliability (Shim et al. 1999). Career attributes (reasons for choosing any type of job) were measured by a series of 19 items with reference to a sevenpoint scale (1 = not important at all, 7 = extremely important). These items were adopted from Shim et al. (1999) and Knight, Crutsinger, and Kim (2006). A single item was used to measure respondents' likelihood of pursuing careers in retailing upon graduation, evaluated on a seven-point scale where $1=$ extremely unlikely, and $7=$ extremely likely (Anderson et al. 1992).

The sample consisted of undergraduate business students of two public universities in Malaysia. The sample was restricted to seniors to more accurately test the influence of marketing knowledge on perceptions of retail careers. In addition, previous research looked at business students at all class ranks in general (Swinyard, 1981; Swinyard et al. 1991; Broadbridge, 2003a, 2003b; Mokhlis, 2014a, 2014b, 2014c), yet recruiters are predominately interested in seniors. Therefore, it is important to limit this sample to senior business students. Three hundred questionnaires were distributed during regularly scheduled classes, in two separate public universities in May 2014. Students were informed in writing that completing the questionnaire was anonymous, voluntary, and that there were no penalties for not participating.

Of the 300 questionnaires distributed to collaborating faculty, there were 172 useable surveys returned from two universities. Of these, $116(67.4 \%)$ were from University A, and 56 (32.6\%) from University B. The sample was primarily female (78.5\%), Malay ethnicity (79.1\%). Students ranged from 22-28 years, with an average age of 23 (standard deviation 0.94 ). $73.3 \%$ of the respondents were marketing specialization, with the remaining $26.7 \%$ of respondents specializing in finance or operation management.

\section{Results}

The processing and analyzing of data were performed using the descriptive and statistical methods available in the SPSS version 15 for Windows. Exploratory factor analysis was conducted identify the construct dimensions of the LOV and career expectation. The reliability of each measure was determined using Cronbach's alpha. Multiple regression analysis was used to test the hypothesized relationships among the variables.

\subsection{Exploratory Factor Analysis}

Adopting the approach taken by Homer and Kahle (1988) and Shim et al. (1999), a principal components analysis with varimax rotation was initially conducted to identify underlying dimensions of personal values. A number of authors (e.g. Homer \& Kahle, 1988; Shim \& Eastlick, 1998; Shim et al. 1999) recommend that it is prudent to reduce the LOV items to a smaller number of underlying dimensions for predicting attitudes. This approach can overcome concerns regarding 
single-item measurement that are frequently raised in value surveys (Braithwaite \& Scott, 1991; Shim \& Eastlick, 1998). As expected, a two-factor solution for LOV scale was identified (see Table 1). The first LOV factor included five items (i.e. excitement, warm relationship with others, fun and enjoyment in life, being well-respected, and a sense of belonging) and was labeled Social Affiliation. The second LOV factor, labeled Self-Actualizing, included four items (i.e. security, selfrespect, a sense of accomplishment, and self-fulfillment). The total variance explained was 49.5 per cent, and Cronbach's alpha coefficients were .71 and .66 , respectively, indicating high reliability among the construct.

A principal component factor analysis with varimax rotation and eigenvalues of one or greater was conducted on the 19 aspects of job attributes. Items with factor loadings of .50 or more on only one factor were retained. Based on these criteria, six items were dropped, and a four-factor solution was deemed most appropriate. The resulting four factors were labeled Intrinsic Enjoyment, Opportunity, Lifestyle Flexibility, and Extrinsic Compensation (see Table 1). These dimensions accounted for 59 per cent of the variance. Cronbach's alpha coefficients ranged from .53 to .72. The Intrinsic Enjoyment factor included four items (variety of job responsibility, opportunities to contribute to company success, high prestige of the career field, and intellectual stimulation and challenge). The Opportunity factor included three items (fit of job to personality, opportunities to learn new things, and opportunities to make contribution to society). The Lifestyle Flexibility included three items (preferred geographic location, flexible working hours, and sufficient time to engage in leisure activities). Finally, the Extrinsic Compensation factor included three items (good benefits, job security/stability, and good pay).

Table 1: Summary of factor analysis results

\begin{tabular}{lcccc}
\hline Factor name & No. of item & Factor loading & Explained variance (\%) & Alpha \\
\hline Social Affiliation Value & 5 & $.533-.815$ & 27.16 & .71 \\
Self-Actualizing Value & 4 & $.552-.763$ & 22.34 & .66 \\
Intrinsic enjoyment & 4 & $.599-.739$ & 16.01 & .66 \\
Opportunity & 3 & $.537-.769$ & 15.53 & .72 \\
Lifestyle flexibility & 3 & $.545-.761$ & 14.34 & .53 \\
Extrinsic compensation & 3 & $.613-.747$ & 13.08 & .61 \\
\hline
\end{tabular}

\subsection{Hypothesis Testing}

To examine hypothesized relationships, multiple regression was employed that allowed us to scrutinize the contribution of each independent variable to the regression models. The magnitude of each variable was examined by its beta weight whereas the strength of the model was assessed by the percentage of explained variance attributed to the independent variables (R-square). To determine the effect of multicollinearity, the Variance Inflation Factor (VIF) was calculated. A common cutoff threshold is a tolerance value of .10, which corresponds to a VIF value of above 10 (Hair, Anderson, Tatham, \& Black, 1998). All VIF values were represented below 1.534, which were within an acceptable range.

To test $\mathrm{H} 1$, the two subscales of personal values were employed as predictor variables and the four dimensions of job attributes as criterion variables. As shown in Table 2, the four regression equation models significantly explained intrinsic enjoyment $\left[F(2,160)=9.567, p<.001, R^{2}=.107\right]$, opportunity $\left[F(2,163)=15.59, p<.001, R^{2}=.161\right]$, lifestyle flexibility $\left[F(2,162)=15.193, p<.001, R^{2}=.158\right]$, and extrinsic compensation $\left[F(2,163)=30.133, p<.001, R^{2}=.27\right]$. All relationships between values and job attributes were positively correlated, with the exception of the influence of selfactualizing values on intrinsic enjoyment. Self-actualizing values were positively correlated with opportunity $(\beta=.19, p<$ $.05)$, lifestyle flexibility $(\beta=.267, p<.01)$, and extrinsic $(\beta=.323, p<.001)$ career aspects. Social affiliation values were positively related to all four aspects of career expectation: intrinsic enjoyment $(\beta=.227, p<.05)$, opportunity $(\beta=.27, p<$ $.001)$, lifestyle flexibility $(\beta=.189, p<.05)$, and extrinsic compensation $(\beta=.275, p<.001)$. Thus, $\mathrm{H1}$ was fully supported. 
Table 2: Multiple regression analysis between personal values and job attributes

\begin{tabular}{|c|c|c|c|c|}
\hline \multirow[b]{2}{*}{ Predictors } & \multicolumn{4}{|c|}{$\begin{array}{l}\text { Criterion Variables } \\
\text { Standardized Beta Coefficient }(\beta)\end{array}$} \\
\hline & Intrinsic enjoyment & Opportunity & Lifestyle flexibility & Extrinsic compensation \\
\hline Self-actualizing value & $\mathrm{n} / \mathrm{s}$ & $.190 *$ & $.267^{\star \star}$ & $.323^{\star \star \star}$ \\
\hline Social affiliation value & $.227^{\star \star}$ & $.270^{\star \star \star}$ & $.189^{*}$ & $.275^{\star \star *}$ \\
\hline R-square & .107 & .161 & .158 & .27 \\
\hline Adjusted R-square & .096 & .150 & .148 & .261 \\
\hline $\mathrm{F}$ & $9.567^{\star \star \star}$ & $15.59 * \star \star$ & $15.193^{\star \star \star}$ & $30.133^{\star \star *}$ \\
\hline
\end{tabular}

To test $\mathrm{H} 2$ and $\mathrm{H} 3$, two dimensions of personal values and four dimensions of job attributes were used as six predictor variables simultaneously, and retail career intention as the criterion variable (see Table 3). The model significantly explained retail career $\left[F(3,165)=11.559, p<.001, R^{2}=.179\right]$. There were significant positive relationships between intrinsic enjoyment $(\beta=.293, p<.001)$ and lifestyle flexibility $(\beta=.279, p<.001)$ and retail career choice. However, extrinsic compensation $(\beta=-.16, p<.05)$ was negatively related to retail career choice. In summary, three of the four relationships were significant. Therefore, $\mathrm{H} 2$ was accepted, indicating that students who held high expectations for intrinsic enjoyment and lifestyle flexibility were more likely to seek a retail career upon graduation. H3 concerning the indirect relationship between personal values and retail career intention was also supported in that neither the personal value dimensions was shown to be significantly related to retail career intention.

Table 3: Multiple regression analysis between personal values, job attributes and retail career intention

\begin{tabular}{|c|c|}
\hline & $\begin{array}{c}\text { Criterion Variables } \\
\text { Standardized Beta Coefficient ( } \beta \text { ) }\end{array}$ \\
\hline Predictors & Retailing career \\
\hline Self-actualizing value & $\mathrm{n} / \mathrm{s}$ \\
\hline Social affiliation value & $\mathrm{n} / \mathrm{s}$ \\
\hline Intrinsic enjoyment & $.293^{\star \star \star}$ \\
\hline Opportunity & $\mathrm{n} / \mathrm{s}$ \\
\hline Lifestyle flexibility & $.279 \star \star \star$ \\
\hline Extrinsic compensation & $-.160^{\star}$ \\
\hline R-square & .179 \\
\hline Adjusted R-square & .149 \\
\hline $\mathrm{F}$ & $11.559 * \star \star$ \\
\hline
\end{tabular}

\section{Conclusion}

The current study contributes, to some extent, to extending the means-end theory by empirically testing the influences of personal values on college students' perceived importance of job attributes and their choice behavior regarding retailing careers. The findings confirm that a value-attribute-behavior hierarchy model can be applied not only to choice behavior in shopping contexts but also to career choice. This study empirically showed that both dimensions of personal values, namely self-actualizing and social affiliation, serve to influence students' perceived importance of career attributes. Personal values only have an indirect influence on retail career choice through career attributes, suggesting that perceived importance of career attributes had a mediating role in the value-attribute-behavior model. This finding lends support to Shim et al. (1999), who found that the influence flows from personal values to attitudes to specific behaviors and that personal values have only an indirect effect on choice behavior through career attitudes.

The findings of this study indicate that a value-attribute-behavior model can serve as a useful framework in predicting college students' likelihood of choosing retailing careers. The causal flow of personal value-attribute-behavior in the context of a retail career choice implies that retail firms can positively influence student behavior by developing recruitment strategies aimed at appealing to personal values. These values in turn will have direct influence on the student evaluation of career attributes as well as indirect influence on the choice behavior prompted by these evaluations. The study also found that intrinsic enjoyment was the most important factor that influences retail career choice in the future. Thus, for retail recruiters to attract the best candidates for management trainees, the first priority is to build career 
preference based on intrinsic aspects such as variety of job responsibility, opportunities to contribute to company success, high prestige of the career field, and intellectual stimulation and challenge.

From an innovative education point of view, it would seem that there is a need to go beyond lectures to active involvement of students in processes and activities that will set the values and attitude that lead to retail career choice. Such activities would include decision case analyses, fieldwork trips, role plays, and simulations. In addition, quality internships, professional development programs, and other interactions with practicing retail managers would seem valuable in forming and supporting values and attitude that might lead to retail career choice.

Although this study provides some promising insights, certain limitations in the design of the research should be recognized in order to guide future exploration of this subject. For instance, a limitation of the study was identified by the low R-square values of each model. This finding was similar to past research on retail career preference and choice (e.g. Anderson et al. 1992; Goldsberry et al. 1999). The low R-square values suggest the need to identify additional predictor variables. A second limitation was the demographic profile. The primarily female, Malay sample from two universities is not representative of the general student population. Further research endeavors should consist of obtaining a representative sample of the population.

\section{References}

Añaña, E.D.S. \& Nique, W.M. (2010). Personal values in relation to graduate career choices. International Journal of Public Sector Management, 23(2), 158-168.

Anderson, C.H., Stanley, S.R., \& Parker, T.H. (1992). Student perceptions of marketing careers and career decision influences: A retailing example. Journal of Marketing Education, 14(1), 46-56.

Bent, R., \& Freathy, P. (1997). Motivating the employee in the independent retail sector. Journal of Retailing and Consumer Services, $4(3), 201-208$.

Braithwaite, V.A., \& Scott, W.A. (1991). Values. In J. Robinson, P.R. Shaver \& L.S. Wrightsman (Eds.), Measures of personality and social psychological attitudes (pp. 661-753). New York: Academic Press.

Broadbridge, A. (2003a). Student perceptions of retailing as a destination career. International Journal of Retail \& Distribution Management, 31(6), 298-309.

Broadbridge, A. (2003b). The appeal of retailing as a career 20 years on. Journal of Retailing and Consumer Services, 10(5), 287-296.

Broadbridge, A.M., Maxwell, G.A., \& Ogden, S.M. (2007). Students' views of retail employment - key findings from Generation Ys. International Journal of Retail \& Distribution Management, 35, 982-992

Broadbridge, A.M., Maxwell, G.A., \& Ogden, S.M. (2009). Selling retailing to Generation Y graduates: Recruitment challenges and opportunities. International Review of Retail, Distribution and Consumer Research, 19(4), 405-420.

Brunso, K., Scholderer, J., \& Grunert, K.G. (2004). Closing the gap between values and behavior - a means-end theory of lifestyle. Journal of Business Research, 57(6), 665-670.

Commins, J., \& Preston, D. (1997). The attractiveness of retailing as a career for graduates: An update. International Journal of Retail \& Distribution Management, 25(4), 120-125.

De Hauw, S. \& De Vos, A. (2010). Millenials' career perspective and psychological contract expectations: Does the recession lead to lowered expectations? Journal of Business and Psychology, 25(2), 293-302.

Foskett, N. \& Hemsley-Brown, J. (2002). Choosing futures: Young people's decision making in education, training, and careers markets. Abingdon: Routledge.

Fotopoulos, C., Krystallis, A., \& Mess, M. (2003). Wine produced by organic grapes in Greece: Using means-end chains analysis to reveal organic buyers' purchasing motives in comparison to the non-buyers. Food Quality and Preference, 14(7), 549-566.

Glass, A. (2007). Understanding generational differences for competitive success. Industrial and Commercial Training, 38(2), 98-103.

Grunert, K.G. \& Grunert, S.C. (1995). Measuring subjective meaning structures by laddering method: Theoretical considerations and methodological problems. International Journal of Research in Marketing, 12(3), 209-225.

Hair, J.F., Black, W.C., Babin, B.J., Anderson, R.E., \& Tatham, R.L. (2006). Multivariate data analysis (6th ed.). New Jersey: Pearson Education Inc.

Hojat, M., Brigham, T.P., Gottheil, E., Xu, G., Glaser, K., \& Veloski, J.J. (1998). Medical students' personal values and their career choices: A quarter-century later. Psychological Reports, 83(1), 243-248.

Kahle, L. R. (1983). Social values and social change: Adaptation to life in America. New York: Praeger.

Knight, D.K., Crutsinger, C., \& Kim, H.J. (2006). The impact of retail work experience, career expectation, and job satisfaction on retail career intention. Clothing \& Textiles Research Journal, 24(1), 1-14.

Martin, C. (2005). From high maintenance to high productivity: What managers need to know about Generation Y. Industrial and Commercial Training, 37(1), 39-44.

McGuire, D., Todnem By, R., \& Hutchings, K. (2007). Towards a model of human resource solutions for achieving intergenerational interaction in organizations. Journal of European Industrial Training, 31(8), 592-608.

Mokhlis, S. (2014a). What are students' perceptions of retailing as a career choice? Academic Journal of Interdisciplinary Studies, 3(1), 363-368. 
Mokhlis, S. (2014b). The image of retailing as a graduate career: Evidence from Malaysia. International Business Management, 8(2), 146-152.

Mokhlis, S. (2014c). Marketing students' perception of retailing as a career option. The Social Sciences, 9(6), 486-491.

Morton, L.P. (2002). Targeting Generation Y. Public Relations Quarterly, 47(2), 46-48.

Oliver, D. (2006). An expectation of continued success: The work attitudes of Generation Y. Labour and Industry, 17(1), 61-84.

Rahim, R. (2012, July 10). Grads turning their backs on retail industry, says MRCA. The Star. Retrieved from http://thestar.com.my/ news/story.asp?file=/2012/7/10/nation/11634400\&sec=nation

Rokeach, M. (1973). The nature of human value. New York: Free Press.

Rolfe, H. (2001). The effect of tuition fees on students' demands and expectations: Evidence from case studies of four universities. Discussion Paper 190. London: National Institute of Economic and Social Research.

Shim, S. \& Eastlick, M.A. (1998). The hierarchical influence of personal values on mall shopping attitude and behavior. Journal of Retailing, 74(Spring), 139-152.

Shim, S., Warrington, P., \& Goldsberry, E. (1999). A personal value-based model of college students' attitudes and expected choice behavior regarding retailing careers. Family and Consumer Sciences Research Journal, 28(1), 28-51.

Swinyard, W.R. (1981). The appeal of retailing as a career. Journal of Retailing, 57(4), 86-97.

Swinyard, W.R., Langrehr, F.W., \& Smith, S.M. (1991). The appeal of retailing as a career: a decade later. Journal of Retailing, 67(4), 451-465.

Williams, T.G. \& P. Hall (2006). Personal values and management priorities: Marketing students vs. top level marketing managers. Marketing Management Journal, 16(1), 104-124.

Whysall, P., Foster, C., \& Harris, L. (2009). Job dissatisfaction among retail employees: A study of three leading UK retailers. The International Review of Retail, Distribution and Consumer Research, 19(2), 179-198. 